\title{
Leaf Tissue Water Relations Are Associated with Drought-Induced Leaf Shedding in Tropical Montane Habitats
}

\author{
M. A. Sobrado \\ Laboratorio de Biología Ambiental de Plantas, Departamento de Biología de Organismos, Universidad Simón \\ Bolívar; Caracas, Venezuela \\ Email: msobrado@usb.ve
}

Received 1 July 2015; accepted 22 August 2015; published 28 August 2015

Copyright (C) 2015 by author and Scientific Research Publishing Inc.

This work is licensed under the Creative Commons Attribution International License (CC BY).

http://creativecommons.org/licenses/by/4.0/

(c) (i) Open Access

\begin{abstract}
In tropical montane areas, water limitation is a common occurrence, and both pioneer and forests species experience water stress during the dry season. Adjustments of leaf area during periods of drought allow for the maintenance of the water supply and physiological functions of the remaining leaves. Here, we compared leaf blade water relations between pioneer and forest tree species. Leaf pressure-volume (P-V) curves were determined from samples taken prior to the dry season, to assess how leaves of the different species were adapted to prepare for and endure water deficits. The following parameters were calculated: osmotic potential at full $\left(\Psi_{\pi(100)}\right)$ and zero $\left(\Psi_{\pi(0)}\right)$ turgor, relative water content at zero turgor $\left(\mathrm{RWC}_{0}\right)$, volumetric elastic modulus $(\varepsilon)$ as well as apoplasm (A) and symplasm (S) water content and their ratio (A/S). Although the pioneer and forest species occupied contrasting habitats, and both groups were clearly differentiated with respect to their water transport capability and water use efficiency, their leaf tissue water relations showed clear differences across species but not between the groups. Some species underwent leaf shedding and accumulated xylem embolisms during the dry season, and their leaves had high cell elasticity. Consequently, these species presented large cell volume changes with turgor loss. Conversely, species with rigid leaves were able to undergo lower leaf turgor with only small changes in cell volume during drought, which might aid to preserve leaf cell function, maintain water uptake, and consequently avoid accelerated leaf senescence and shedding during the dry season.
\end{abstract}

\section{Keywords}

Apoplasm, Cell Volume Reduction, Drought Adaptations, Drought-Induced Leaf-Sheding, Forest Species, Pioneer Trees, Pressure-Volume Analysis, Rigid Cells, Symplasm, Tropical Forests, Volumetric Elastic Modulus, Water Relations 


\section{Introduction}

The changes in an ecosystem that follow a disturbance are collectively called succession, which is a dynamic and continuous process, often occurring gradually over time [1]. The broadest distinction between trees in a succession are the pioneer trees that are more prominent in open areas and absent from the forests, and forest trees that contribute to the canopy of a mature forest [2]. Compared to forest species, pioneer species are prolific seeders, fast-growing, short-lived, generally shade intolerant and with high rates of mortality under resource deprivation. Later successional species are shade tolerant and generally grow slowly [1] [3]. Thus, after stand-scale disturbance of natural forests, the landscape changes into patchy vegetation with defined areas including pioneer species and different degree of successional forests. Resource availability and environmental conditions as well as biotic factors vary within the whole landscape [4] [5]. In open habitats occupied by pioneer species forming sparse communities, competition for water and nutrients is lower in comparison to forest habitats [6]. In addition, open habitats created by deforestation experience relatively high variation in light intensity, temperature and water availability as compared to forest habitats [7] [8]. In late succession forest, the environmental conditions tend to be less variable and extreme. In forest areas, solar radiation is received by the canopy and heat is dissipated efficiently by transpiration. Conversely, in open areas light is received by the soils and heat is dissipated by convection which is a less efficient process.

The behavior of pioneer species is characteristically opportunistic because resources are utilized in accordance with their availability in the environment [9]. This results in larger maximum photosynthesis and growth rates as compared to forest species [7]-[9]. Additionally, within-leaf $\mathrm{N}$ allocation differs between pioneer and late successional forest species, with a trade-off between investment in carboxylation and bioenergetics (higher in pioneer species) versus investment in light-harvesting complexes (higher in forest species) [10]. Whole tree plant hydraulic conductance as well as leaf water loss is larger in pioneer as compared to forest species [11] [12]. Thus, opportunistic pioneer species are also more efficient in conducting water to their leaves [13] [14]. However, these species exhibit less control over water use compared to forest species [14] [15]. Overall, pioneer species are characterized by high rates of water loss and hydraulic conductance as well as low leaf water use efficiency compared to forest species [14]. Species that occupy different niches in successional habitats may greatly differ in water relations characteristics such as leaf solute concentration and cell wall elasticity [16]. These characteristics are vital determinants of the turgor maintenance required for growth as available water declines during drought. Thus, a clear understanding of the underlying leaf tissue water relations is crucial to fully assessment of drought adaptations of pioneer and late successional forest species.

This study was carried out using pioneer and successional forest species in a lower montane area with seasonal rains. Water limitation is a common occurrence, and both pioneer and forests species experience some degree of water stress during the dry season. In several species, adjustments to total leaf area during periods of drought allow for the maintenance of the water supply and physiological functions of the remaining leaves [14]. It is currently unknown whether leaf tissue water relations are clearly differentiated between forest species and opportunistic pioneer species. In this study, we compared leaf blade water relations between pioneer and forest tree species in tropical montane habitats. A more complete understanding of the adaptations of leaf tissue to withstand drought can provide further information concerning the responses of trees to change water availability in their native habitats. Such information can be viewed in light of previous ecophysiological findings in these habitats and species [14] [17] to gain a more thoroughly understanding of the tree species inhabiting low montane areas in tropical environments.

\section{Material and Methods}

\subsection{Study Site and Tree Species}

The area under study was a tropical montane forest zone at $1200 \mathrm{~m}$ of elevation surrounding the Universidad Simon Bolivar campus in Caracas, Venezuela $\left(10^{\circ} 20^{\prime} \mathrm{N}, 66^{\circ} 50^{\prime} \mathrm{W}\right)$. Annual rainfall is in the range of $800-1000$ $\mathrm{mm}$, but occurs seasonally with a relative dry period between January and April [18]. During the wet season, the foliage grows rapidly in both habitats and at dry season onset the leaves are fully expanded and generally healthy. The vegetation in the area is patchy and includes late successional forest areas that were once part of coffee plantations, as well as deforested areas that are mainly occupied by pioneer trees [17]. Trees comprising much of the forest grow to 25 - $30 \mathrm{~m}$ tall and usually form a close canopy. Conversely, pioneer species grow up 
to 6 - $8 \mathrm{~m}$ tall and are sparsely arranged in deforested zones. The study focused on leaf tissue water relations of two pioneer and two forest species. The two evergreen pioneer species Oyedaea verbesinoides DC (Asteraceae) and Clethra lanata M. Martens \& Galeotti (Clethraceae) were selected from deforested areas. From the forest areas, the brevi-deciduous Croton xanthochloros Croizat (Euphorbiaceae) and the evergreen Ficus mathewsii (Miq) Miq (Moraceae) were selected for study. Measurements were taken from three tagged trees per species as previously described [14] [17]. Details concerning characteristics of terminal branches and leaves of the species in the habitats as previously reported are summarized in Table 1 [9] [12]. Leaf blade thickness and dry mass to leaf area ratio (SW) tended to be higher in the forest species F. mathewsii compared to the other tree species. Leaf water potential $(\Psi)$ in all species is higher during the wet season and declines during the dry season (Table 1). Trees suffer xylem embolisms as shown by a co-occurring reduction of specific conductivity $\left(K_{s}\right)$ of leafbearing terminal stems during the dry season. The forest species $C$. xanthochloros exhibits the largest reduction in water potential, the highest occurrence of xylem embolisms and accounts for the largest percentage of leaf shedding (65\%) during the dry season. During very dry years, trees of this species shed all of their leaves. Conversely, the forest species $F$. mathewsii does not shed leaves and $\mathrm{K}_{\mathrm{s}}$ is not reduced during the dry season. The two pioneer species exhibit comparable levels of $K_{s}$ reduction during the dry season and an intermediate degree of leaf shedding (28\% - 34\%) (Table 1$)$.

\subsection{Leaf Tissue Water Relations}

Pressure-volume (P-V) curves were determined from samples collected in the field at predawn from each of the three tagged trees. On the day of sampling, twig amounting to 6 - 9 samples per species was wrapped in plastic bags and taken to the laboratory for immediate measurements. Upon the onset of the dry season (generally in January), leaves begin to senesce and are shed. Sampling was done between August and December of 2014 on terminal branches of the outer part of the canopy bearing full mature leaves. This sampling period was selected to best assess how leaves of the different species are adapted to prepare for and endure water deficits.

To construct the P-V curves, the twigs were allowed to dehydrate by transpiration on the laboratory bench. During dehydration, the fresh mass (FM) was determined using an analytical balance (MettlerAE260 Delta Range, Mettler Toledo Intl. Inc.), and $\Psi$ was immediately measured using a pressure chamber (Plant water status console Model 3005, Soil Moisture Equipment Corp. Santa Barbara, California, USA). Measurements were repeated at intervals until leaves presented visible damage due to dehydration. Then, the twigs were oven-dried at $70^{\circ} \mathrm{C}$ until constant weight to obtain their dry mass (DM). Values of FM and DM were used to determine the water content (WC = FM-DM) at each dehydration level. Subsequently, the relative water contents (RWC) were determined as the percentage of the initial maximum WC. The reciprocal of $\Psi(1 / \Psi)$ was plotted as a function of RWC where the linear part of the curves provides estimates of the osmotic potentials $\left(\Psi_{\pi}\right)$ over the whole range of RWC. Linear regression analyses of the plots were used to calculate the osmotic potential at full $\left(\Psi_{\pi(100)}\right)$ and zero $\left(\Psi_{\pi(0)}\right)$ turgor, RWC at zero turgor $\left(\mathrm{RWC}_{0}\right)$, apoplasm (A) and symplasm (S) water content [19] [20].

Table 1. Summary of leaf and wood characteristics of terminal twigs of pioneer and forest species.

\begin{tabular}{ccccc}
\hline Parameter & \multicolumn{2}{c}{ Pioneer Species } & \multicolumn{2}{c}{ Forest Species } \\
\hline & C. lanata & O. verbesinoides & C. xanthochloros & F. mathewsii \\
\hline Thickness $(\mu \mathrm{m})$ & 190 & 182 & 202 & 309 \\
$\mathrm{~S}_{\mathrm{w}}\left(\mathrm{g} \cdot \mathrm{m}^{-2}\right)$ & 105 & 109 & 97 & 291 \\
$\mathrm{~W}_{\mathrm{c}}\left(\mathrm{g} \cdot \mathrm{m}^{-2}\right)$ & 260 & 251 & 271 & 409 \\
$\mathrm{WS} \Psi(\mathrm{MPa})$ & -1.30 & -0.87 & -0.73 & -1.16 \\
$\mathrm{DS} \Psi(\mathrm{MPa})$ & -1.51 & -2.00 & -2.45 & -1.45 \\
WS K $\left(\mathrm{kg} \cdot \mathrm{s}^{-1} \cdot \mathrm{MPa}^{-1} \times 10^{-4}\right)$ & 7.05 & 3.16 & 7.79 & 1.04 \\
DS K ${ }_{\mathrm{s}}$ reduction $(\%)$ & 26.3 & 29.1 & 37.9 & 0 \\
DS Leaf area reduction (\%) & 28.2 & 34.3 & 64.5 & 0 \\
\hline
\end{tabular}

Leaf thickness, dry mass per unit leaf area (Sw), water content (Wc), wet season (WS) and dry season(DS) water potential ( $\Psi$ ), as well as terminal branch specific conductivity $\left(\mathrm{K}_{\mathrm{s}}\right)$ and reduction of both $\mathrm{K}_{\mathrm{s}}$ and leaf area during DS as percentage of values found during WS, in two pioneer species (A-B: C. lanata and O. verbesinoides) and two forest species (C-D: C xantochloros and F. mathewsii) from tropical montane habitats as we reported previously in the same habitats and species [9] [12]. 
Extrapolation at the abscissa-intercept provided $\left(\Psi_{\pi(100)}\right)^{-1}$, and that at the turgor loss provided $\left(\Psi_{\pi(0)}\right)^{-1}$ as well as the respective RWC at zero turgor $\left(\mathrm{RWC}_{0}\right)$. Extrapolation to the ordinate-intercept provided a dividing point between $S$ and A percentages. Turgor pressure $\left(\Psi_{\mathrm{p}}\right)$ was obtained by subtracting from $\Psi$ values the estimated $\Psi_{\pi}$ from the linear regression analysis. Afterwards, the volumetric elastic modulus $(\varepsilon)$ was calculated as the slope of the relationship of turgor pressure $\left(\Psi_{\mathrm{p}}\right)$ above zero as a function of RWC [21].

\subsection{Statistical Analysis}

One-way analysis of variance (ANOVA) followed by the Holm-Sidak test was used to compare data across species in the case that data were normally distributed and of equal variance. ANOVA-on-ranks followed by a Tukey test was used in the case that data were not normally distributed and/or of unequal variance. The significance level was set at $P<0.05$. All analyses were performed using SigmaPlot 11.1 software for Windows (Systat Software, Inc, Chicago, Illinois, USA.).

\section{Results and Discussion}

Parameters concerning leaf tissue water relations obtained from the pressure-volume curves are shown in Table 2. The osmotic potential at full turgor $\left(\Psi_{\pi(100)}\right)$ was significantly lower in the forest species (FS) F. mathewsii and the pioneer species (PS) C. lanata compared to O. vervesinoides (PS) and C. xanthochloros (FS). Leaf $\Psi_{\pi(100)}$ and $\Psi_{\pi(0)}$ have been highly correlated in a number of studies [22]. Thus, it is consistent that the osmotic potential at zero turgor $\left(\Psi_{\pi(0)}\right)$ showed a similar pattern, with the highest values found in O. vervesinoides and $C$. xanthochloros (Table 2). These results demonstrate a high solute concentration (low $\Psi_{\pi}$ ) in leaf cells of $F$. mathewsii (FS) and C. lanata (PS) compared to the other two species (Figure 1). Species with lower $\Psi_{\pi}$ had larger turgor pressure $\left(\Psi_{\mathrm{t}}\right)$ values at full hydration whereas $\Psi_{\pi(0)}$ represents the $\Psi_{\pi}$ and $\Psi$ upon loss of turgor. Therefore, $F$ mathewsii and C. lanata had the larger $\Psi_{\mathrm{t}}$ at zero $\Psi$, and maintained positive $\Psi_{\mathrm{t}}$ at lower $\Psi$ (Figure 2) compared to O. verbesinoides (PS) and C. xanthochloros (FS). A large $\Psi_{\mathrm{t}}$ favors leaf photosynthesis and other physiological processes related to growth maintenance. Leaf $\Psi_{\pi}$ varies widely due to differences in genotype, environment and physiological plasticity. The range of $\Psi_{\pi}$ found in this study compared well to those values found under mesic environments [23]. The $\Psi$ measured previously under field conditions during the dry season was within the range of turgor maintenance in F. mathewsii (FS) and C. lanata but not in the range observed for $O$. verbesinoides (PS) and C. xanthochloros (FS) (Table 1, Figure 2) [14]. The most likely explanation is that the midday $\Psi$ drop measured in $O$. verbesinoides and $C$. xanthochloros in the field was overestimated in the dry season measurements when terminal branches were partially embolized and defoliated (Table 1) [14]. Accurate measurements of $\Psi$ using a pressure chamber in these conditions is challenging because pressurization could induce additional xylem embolization leading to very low $\Psi$.

$\Psi_{\mathrm{t}}$ is regulated by $\Psi_{\pi}$ and also by cell wall elasticity, which depends on the biomechanical properties of the

Table 2. Characteristics of the leaf tissue water relations of two pioneer and two forest species.

\begin{tabular}{|c|c|c|c|c|}
\hline \multirow[t]{2}{*}{ Parameter } & \multicolumn{2}{|c|}{ Pioneer Species } & \multicolumn{2}{|c|}{ Forest Species } \\
\hline & C. lanata & O. verbesinoides & C. xanthochloros & F. mathewsii \\
\hline$\Psi_{\pi(100)}(\mathrm{MPa})$ & $-1.32(0.11) \mathrm{a}$ & $-1.06(0.04) b$ & $-1.08(0.05) b$ & $-1.34(0.06) \mathrm{a}$ \\
\hline$\Psi_{\pi(0)}(\mathrm{MPa})$ & $-1.69(0.10) b$ & $-1.31(0.05) \mathrm{c}$ & $-1.42(0.06) \mathrm{c}$ & $-1.98(0.1) \mathrm{a}$ \\
\hline $\mathrm{RWC}_{0}(\%)$ & $83.7(0.6) b$ & $80.9(0.3) \mathrm{c}$ & $82.9(0.6) b$ & $87.1(0.8)$ a \\
\hline$\varepsilon(\mathrm{MPa})$ & $7.43(055) b$ & $4.73(0.98) \mathrm{c}$ & $7.23(0.80) \mathrm{b}$ & $13.84(1.72) \mathrm{a}$ \\
\hline A (\%) & $21.4(0.6) \mathrm{b}$ & $16.9(1.4) \mathrm{b}$ & 20.9 (3.1) b & $44.8(5.0) \mathrm{a}$ \\
\hline S (\%) & $78.6(0.6) \mathrm{a}$ & $83.0(1.4) \mathrm{a}$ & 79.1 (3.1) a & $55.2(5.0) \mathrm{b}$ \\
\hline $\mathrm{A} / \mathrm{S}$ & $0.31(0.13) \mathrm{b}$ & $0.21(0.02) \mathrm{c}$ & $0.27(0.05) \mathrm{bc}$ & $0.87(0.17) \mathrm{a}$ \\
\hline
\end{tabular}

Pressure-volume parameters: osmotic potential at full $\left(\Psi_{\pi(100)}\right)$ and zero turgor $\left(\Psi_{\pi(0)}\right)$, relative water content at zero turgor $\left(\mathrm{RWC}_{0}\right)$, volumetric elastic modulus $(\varepsilon)$, apoplastic (A) and symplasmic (S) water content and A to $\mathrm{S}$ ratio (A/S). Measurements were taken of the pioneer species $C$. lanata and $O$. verbesinoides and the forest species $C$. xanthochloros and F. mathewsii from tropical montane habitats. Each value is the mean \pm standard error (SE) of measurements in six to nine samples taken from three trees per species. For each parameter, the mean followed by the same letter were not statistically different, and those followed for different letters were statistically different at $P<0.05$. 

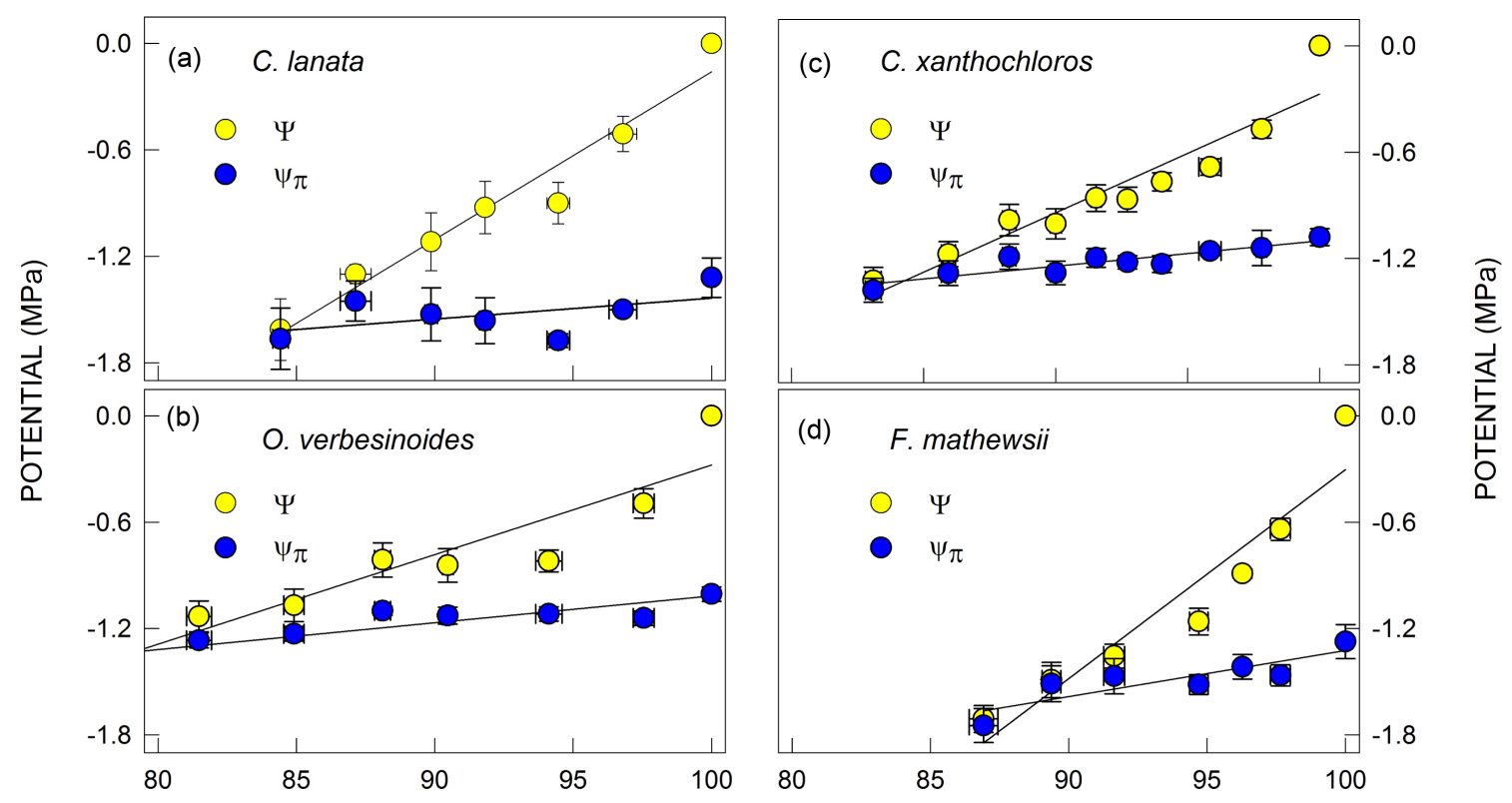

RELATIVE WATER CONTENT (\%)

Figure 1. Leaf water ( $\Psi$, yellow) and osmotic ( $\Psi_{\pi}$, blue) potentials as a function of relative water content in two pioneer species (a) (b): C. lanata and O. verbesinoides and two forest species (c) (d): C. xanthochloros and F. mathewsii from tropical montane habitats. Plots were derived from 6 - 9 pressure-volume $(\mathrm{P}-\mathrm{V})$ curves for each species. Values are presented as means $\pm \mathrm{SE}$.
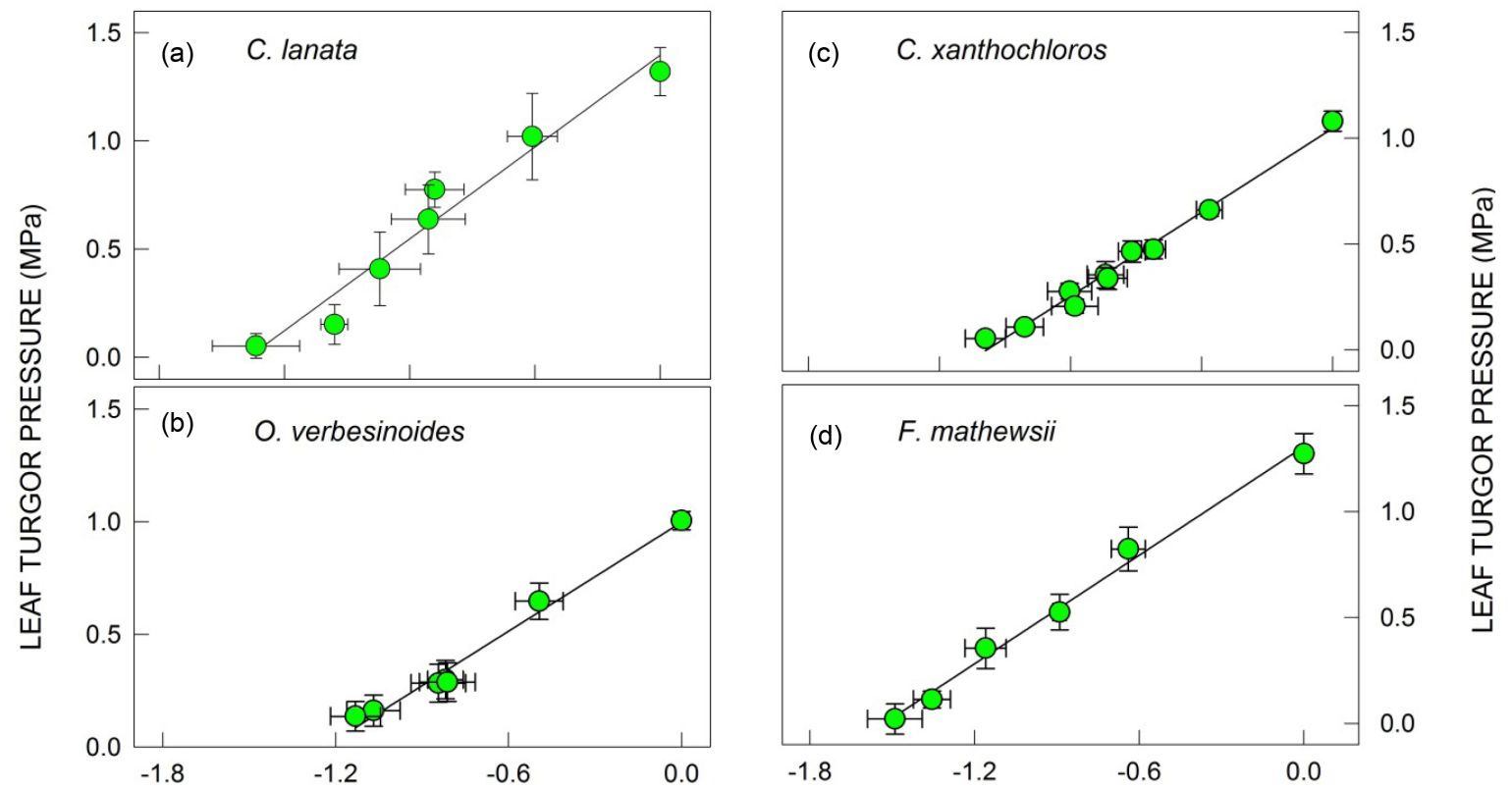

LEAF WATER POTENTIAL (MPa)

Figure 2. Leaf turgor pressure $\left(\Psi_{\mathrm{t}}\right)$ as a function of leaf water potential $(\Psi)$ in two pioneer species (a) (b): $C$. lanata and $O$. verbesinoides and two forest species (c) (d): C. xanthochloros and F. mathewsii from tropical montane habitats. Plots were derived from 6 - 9 pressure-volume $(\mathrm{P}-\mathrm{V})$ curves for each species. Values are presented as means $\pm \mathrm{SE}$.

leaf cells [24] [25]. Assessment of the change in $\Psi_{t}$ per unit of change in cell volume or relative water content (RWC) provides the volumetric elastic modulus $(\varepsilon)$. Thus, leaves with low $\varepsilon$ have more elastic cells that allow 
for larger cell volume reduction and still maintain turgor. By contrast, leaves with cells of low elasticity (high $\varepsilon$ ) lose turgor with a correspondingly small reduction in cell volume. In general, leaf cells of high $\varepsilon$ possess thicker cell walls leading to less elastic cells [26]. The decline of cell volume with turgor maintenance in elastic cells (low $\varepsilon$ ) or avoiding large changes in cell volume within the range of turgor maintenance in rigid cells (high $\varepsilon$ ) may both be adaptive responses in certain environments. Increase in $\varepsilon$ and a decline in $\Psi_{\pi}$ aids in the maintenance of the $\Psi$ gradient for water uptake with small changes in cell water content [27]. The ability to generate large $\Psi$ gradients allows plants to maximize gas exchange, enhancing carbon gain and growth. Declines in $\varepsilon$ facilitate turgor maintenance over a wide range of water contents and $\Psi$ values by effectively accumulating solutes through reduction of cell volume [24]. Here, we found that the species characterized by more elastic leaf tissue and whose $\Psi_{\pi}$ was low (C. lanata; PS) or high (O. verbesinoides and C. xanthochloros) also exhibited some degree of leaf shedding during the dry season (Table 1, Table 2 and Figure 1). Partial defoliation leads to maintenance of the physiological functions of the remaining leaves [14]. Consistent with this observation, the species $O$. verbesinoides (PS) with the lowest $\varepsilon$ (4.7MPa) tended to lose turgor at lower RWC compared to the other species (Figure 1). Conversely, F. mathewsii (FS) has the most rigid leaf tissue ( $\varepsilon=13.8 \mathrm{MPa})$ and lost turgor at significantly higher RWC (Figure 1, Table 2). The responses of $C$. lanata (PS) and C. xanthochloros (FS) were intermediate between these two extremes. The species F. mathewsii (FS), exhibiting both the highest leaf solute concentration as well as the lowest elasticity, is notable for not shedding leaves during the dry season. It has been reported that avoidance of extreme reductions in cell volume during drought in leaves of low elasticity may be important for the protection of membrane integrity and macromolecules as well as the maintenance of metabolic activity [28]. This may be true in F. mathewsii (PS), whose leaves were not shed during the dry season (Table 1). In tropical dry forests as well, evergreen species possess leaves with high solute concentrations and low elasticity compared to drought-deciduous species [29].

The apoplasm (A) water content was statistically the highest in F. mathewsii (45\%) which also had the thickest leaves among the trees in this study. We speculate that $F$. mathewsii leaf cells correspondingly have thick cell walls contributing to large apoplasm spaces (Table 1 and Table 2). Values of A in the other three species bearing thinner leaves were comparatively lower between about 17\% and 21\% (Table 1 and Table 2). Conversely, F. mathewsii had the significantly lowest symplasm (S) water content of about $55 \%$ as compared to $78 \%-83 \%$ in the other species (Table 2). With respect to A to $\mathrm{S}$ ratios $(\mathrm{A} / \mathrm{V})$, the lowest value of about 0.21 corresponded to the PS O. verbesinoides and the highest value of about 0.87 to the FS F. mathewsii (Table 2). In general, plants possess higher A/S under unfavorable water conditions over space and time, and therefore it has been considered as an important indicator of plant drought resistance [30]. Leaves with lower A/S are more susceptible to drought as compared to those with higher values. Importantly, this was the case in this study, where the relative large A/S value was found in the FS F. mathewsii which possessed more drought resistant leaves.

\section{Concluding Remarks}

This study compared the water relations of two pioneer and two forest species in tropical montane habitats. Although the pioneer and forest species occupied contrasting habitats and both groups were clearly differentiated with respect to their water transport capability and water use efficiency, their leaf tissue water relations showed clear differences across species but not between the groups. However, all the species had different physiological and ecological attributes in order to adapt to drought by avoiding water loss by leaf area reduction or enduring drought with more resistant leaf tissue. The leaf tissue water relations characteristic of each species were associated with these differing capacities of the species to tolerate periods of water deficit. The pioneering species $C$. lanata and $O$. verbesinoides as well as the forest species $C$. xanthochloros undergo leaf shedding and accumulate xylem embolisms during the dry season. Leaves of $O$. verbesinoides (PS) and of $C$. xanthochloros (PS) exhibit low levels of solute concentration (high $\Psi_{\pi}$ ) and lost turgor at higher $\Psi$ as compared to C. lanata (PS). Leaves of these three species with high cell elasticity (low $\varepsilon$ ) presented large cell volume changes with loss of turgor (low RWC) compare to F. mathewsii. The forest species F. mathewsii retained its leaves and did not experience xylem embolisms during the dry season. The rigid leaves (high $\varepsilon$ ) of $F$. mathewsii were able to undergo lower leaf $\Psi$ with only small changes in RWC. The small changes in cell volume during drought may aid to preserve leaf cell function, maintain a positive $\Psi$ gradient between leaf and soil for water uptake, and conse- 
quently avoid accelerated leaf senescence and shedding during periods of water deficit during the dry season.

\section{Acknowledgements}

DID-USB-Fondo de Trabajo 1014-2015 provided partial financial support. Anonymous reviewers provided helpful suggestions to improve the manuscript.

\section{References}

[1] Binelli, E.K., Gholz, H.K. and Duryea, M.L. (2001) Chapter 4: Plant Succession and Disturbances in the Urban Forest Ecosystem. Florida Cooperative Extension Service, Institute of Food and Agricultural Sciences, University of Florida, Miami, 1-20. https://edis.ifas.ufl.edu/pdffiles/FR/FR06800.pdf

[2] Finegan, B. (1984) Forest Succession. Nature, 312, 109-114. http://dx.doi.org/10.1038/312109a0

[3] Nogueira, A., Martinez, C.A., Ferreira, L.L. and Prado, C.H.B.A. (2004) Photosynthesis and Water Use Efficiency in Twenty Tropical Tree Species of Differing Succession Status in a Brazilian Reforestation. Photosynthetica, 42, 351356. http://dx.doi.org/10.1023/B:PHOT.0000046152.05364.77

[4] Tabarelli, M., Lopes, A.V. and. Peres, C.A. (2008) Edge-Effects Drive Tropical Forest Fragments towards an EarlySuccessional System. Biotropica, 40, 657-661. http://dx.doi.org/10.1111/j.1744-7429.2008.00454.X

[5] Swanson, M.E., Franklin, J.F, Beschta, R.L., Crisafulli, C.M., Dellasala, D.A., Hutto, R.L., Lindenmayer, D.B. and Swanson, F.J. (2011) The Forgotten Stage of Forest Succession: Early-Successional Ecosystems on Forest Sites. Frontiers in Ecology and the Environment, 9, 117-125. http://dx.doi.org/10.1890/090157

[6] Davies, S.J. and Semui, H. (2006) Competitive Dominance in a Secondary Successional Rain-Forest Community in Borneo. Journal of Tropical Ecology, 22, 53-64 http://dx.doi.org/10.1017/S0266467405002944

[7] Bazzaz, F.A. (1979) The Physiological Ecology of Plant Succession. Annual Review of Plant Ecology and Systematic, 10, 351-371. http://dx.doi.org/10.1146/annurev.es.10.110179.002031

[8] Bazzaz, F.A. and Carlton, R.W. (1982) Photosynthetic Acclimation to Variability in the Light Environment of Early and Late Successional Plants. Oecologia, 34, 313-316. http://dx.doi.org/10.1007/BF00379999

[9] Zangerl, A.R. and Bazzaz, F.A. (1983) Responses of an Early and Late Successional Species of Polygonium to Variation in Resource Availability. Oecologia, 56, 397-808. http://dx.doi.org/10.1007/BF00379719

[10] Dusenge, M.E., Wallin, G., Gårdesten, J., Niyonzima, F., Adolfsson, L., Nsabimana, D. and Uddling, J. (2015) Photosynthetic Capacity of Tropical Montane Tree Species in Relation to Leaf Nutrients, Successional Strategy and Growth Temperature. Oecologia, 177, 1183-1194. http://dx.doi.org/10.1007/s00442-015-3260-3

[11] Becker, P., Meinzer, F.C. and Tsuda, M. (1999) Hydraulic Conductance of Angiosperms versus Conifers: Similar Transport Sufficiency at the Whole-Plant Level. Tree Physiology, 19, 445-452. http://dx.doi.org/10.1093/treephys/19.7.445

[12] Becker, P., Meinzer, F.C. and Wullschleger, S.W. (2000) Hydraulic Limitation of Tree Height: A Critique. Functional Ecology, 14, 4-11. http://dx.doi.org/10.1046/j.1365-2435.2000.00397.x

[13] Tyree, M.T., Velez, V. and Dalling, J.L. (1998) Growth Dynamics of Root and Shoot Hydraulic Conductance in Seedling of Five Neotropical Tree Species: Scalling to Show Possible Adaptation to Differing Light Regimes. Oecologia, 114, 293-298. http://dx.doi.org/10.1007/s004420050450

[14] Sobrado, M.A. (2003) Hydraulic Characteristics and Leaf Water Use Efficiency in Trees from Tropical Montane Habitats. Trees: Structure and Function, 17, 400-406. http://dx.doi.org/10.1007/s00468-003-0251-5

[15] Huc, R., Ferhi, A. and Guehl, J.M. (1994) Pioneer and Late Stage Tropical Rainforest Tree Species (French Guiana) Growing under Common Conditions Differ in Leaf Gas Exchange Regulation, Carbon Isotope Discrimination and Leaf Water Potential. Oecologia, 99, 297-305. http://dx.doi.org/10.1007/BF00627742

[16] Abrams, M.D. (1988) Comparative Water Relations of Three Successional Hardwood Species in Central Wisconsin. Tree Physiology, 4, 263-273. http://dx.doi.org/10.1093/treephys/4.3.263

[17] Sobrado, M.A. (2008) Leaf and Photosynthetic Characteristics of Pioneer and Forest Species in Tropical Montane Habitats. Photosynthetica, 46, 604-610. http://dx.doi.org/10.1007/s11099-008-0101-1

[18] Baruch, Z., Hernandez, A.B. and Montilla, M.G. (1989) Dinámica de Crecimiento, Fenología y Repartición de Biomasa en Gramíneas Nativas e Introducidas en una Sabana Neotropical. Ecotrópicos, 2, 1-13.

[19] Tyree, M.T. and Hammel, H.T. (1972) The Measurement of the Turgor Pressure and the Water Relations of Plants by the Pressure-Bomb Technique. Journal of Experimental Botany, 23, 267-282. http://dx.doi.org/10.1093/jxb/23.1.267

[20] Turner, N.C. (1981) Techniques and Experimental Approaches for the Measurement of Plant Water Status. Plant and 
Soil, 58, 339-366 http://dx.doi.org/10.1007/BF02180062

[21] Melkonian, J.J., Wolfe, J. and Stenponkus, P.L. (1982) Determination of the Volumetric Modulus of Elasticity of Wheat Leaves by Pressure-Volume Relations and the Effect of Drought Conditioning. Crop Science, 22, 116-123. http://dx.doi.org/10.2135/cropsci1982.0011183X002200010027x

[22] Maréchaux, I., Bartlett, M., Sack, L., Baraloto, C., Engel, J., Joetzjer, E. and Chave, J. (2015) Drought Tolerance as Predicted by Leaf Water Potential at Turgor Loss Point Varies Strongly Across Species Within an Amazonian Forest. Functional Ecology. http://onlinelibrary.wiley.com/doi/10.1111/1365-2435.12452/abstract

[23] Abrams, M.D. (1988) Sources of Variation in Osmotic Potentials with Special Reference to North American Tree Species. Forest Science, 34, 1030-1046.

[24] Cheung, Y.N.S., Tyree, M.T. and Dainty, J. (1975) Water Relations Parameters on Single Leaves Obtained in a Pressure Bomb and Some Ecological Interpretations. Canadian Journal of Botany, 53, 1342-1346. http://dx.doi.org/10.1139/b75-162

[25] Dainty, J. (1972) Plant Cell Water Relations: The Elasticity of the Cell Wall. Proceedings of the Royal Society of Edinburgh, Section A, Mathematical and Physical Sciences, 70, 89-93.

[26] Saito, T. and Terashima, I. (2004) Reversible Decreases in the Bulk Elastic Modulus of Mature Leaves of Deciduous Quercus Species Subjected to Two Drought Treatments. Plant, Cell and Environment, 27, 863-873. http://dx.doi.org/10.1111/j.1365-3040.2004.01192.x

[27] Bolaños, J.A. and Longstreth, D.J. (1984) Salinity Effects on Water Potential Components and Bulk Elastic Modulus of Alternanthera philoxeroides (Mart.) Griseb. Plant Physiology, 75, 281-284. http://dx.doi.org/10.1104/pp.75.2.281

[28] Clifford, S.C., Stefan, S.K., Corlett, J.E., Jossi, S., Sankhla, N., Popp, M. and Jones, H.G. (1998) The Role of Solute Accumulation, Osmotic Adjustment and Changes in Cell Wall Elasticity in Drought Tolerance in Ziziphus mauritiana (Lamk.). Journal of Experimental Botany, 49, 967-977. http://dx.doi.org/10.1093/jxb/49.323.967

[29] Sobrado, M.A. (1986) Aspects of Tissue Water Relations and Seasonal Changes of Leaf Water Potential Components of Evergreen and Deciduous Species Coexisting in Tropical Dry Forests. Oecologia, 68, 413-416. http://dx.doi.org/10.1007/BF01036748

[30] Xingdon, H.E., Peifang, C., Yubao, G., Jianguo, L., Haitao, W., Pingping, X. and Xu, Z. (2007) Drought Resistance of Four Grasses Using Pressure-Volume Curve. Frontiers in Biology China, 2, 425-430. http://dx.doi.org/10.1007/s11515-007-0065-8 